\title{
HERBAL MEDICINAL PRODUCTS IN OUR ENVIRONMENT
}

\author{
Tímea Kiss* \\ John von Neumann University, Faculty of Horticulture and Rural Development, Hungary \\ https://doi.org/10.47833/2020.1.AGR.007
}

\section{Keywords: \\ Herbs \\ Urbanization \\ Disturbance}

\section{Article history:}

Received 26 Nov 2019

Revised 15 Dec 2019

Accepted 20 Dec 2019

\begin{abstract}
We would think that the ever-appreciated herbs can be harvested almost exclusively in forests and fields. However, many valuable herbs live here in our vicinity, in the cities. Urbanization is arguably the most intense and irreversible ecosystem change on the planet.
\end{abstract}

\section{Introduction}

The human population is concentrated in cities, increasingly isolated from nature. However, many people maintain daily contact with nature through urban public green spaces [4]. In the urban environment, vegetation provides additional ecosystem services such as air purification and temperature reduction [2]. Many species are lost during the conversion of natural habitats [7]. Urban areas are subject to various environmental impacts. These may be those that are not present or less important in other ecosystems [5]. These include significant soil and atmospheric pollution, urban heat island due to high temperatures and increased water stress [5], [6].

\section{Method}

The three sampling areas are located on the outskirts of downtown Kecskemét. The areas are naturally formed grasslands. The lawns are mown three times a year, but there is no other maintenance work (irrigation, nutrient supply). The recordings were made twice before the end of June and before the mowing. In the areas, 5 to 5 squares are randomly selected. For recording, we followed Braun-Blanquet's [3] method using $2 \times 2 \mathrm{~m}$ squares. The species names follow the nomenclature of Simon [9].

\section{Results}

A large proportion of ruderal competitors appear in the areas. Natural disturbance tolerance is only high in two areas. The emerged crop category is represented by specimens of fodder alfalfa (Medicago sativa). The proportion of natural disturbance-tolerant plants (DT) is outstanding in the distribution of the responsible species by Simon's conservation value categories. Weeds (W) are also significantly present.

Herbs: The coverage of herbs found in the species lists [1] exceeded the values of other plants in one area, due to the high proportion of the common purslane (Portulaca oleracea) (Figure 1). The proportion of species numbers is balanced. However, the area with the highest number of species has the lowest proportion of herbs (Figure 2). 


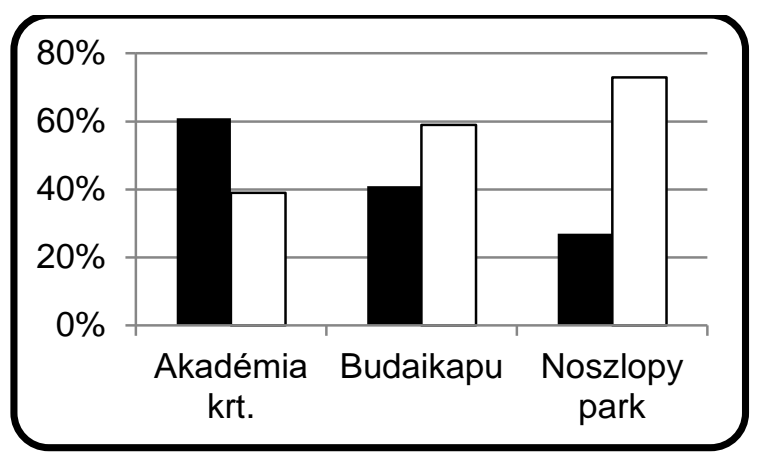

Figure 1: Coverage values for herbs (घHerbs; $\square$ Others)

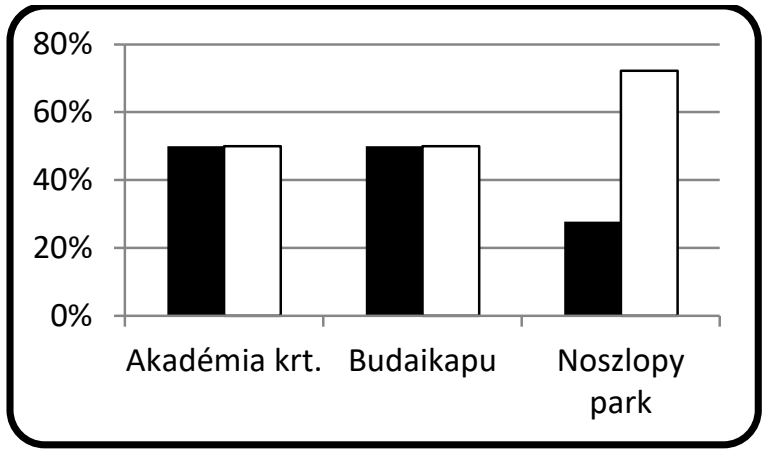

Figure 2: Proportion of herbaceous species (घHerbs; $\square$ Others)

\section{Discussion}

The 'Akadémia krt.' area is primarily rich in weed species, however, it is in this area that the largest number of species which can be used as herbs. Commonly occurring species in coenological surveys are weeds or disturbance-tolerant plants. In all three areas, there are species known (Taraxacum officinale, Plantago lanceolata) or lesser known (Cychorium intybus). So the above study points out that in our immediate, "everyday" environment, there are herbs that have been widely used by our ancestors. Of course, it is important to emphasize that in the collection of herbs, confident plant knowledge and other rules of collection!

\section{Acknowledgment}

Thank you for the support of the research carried out in the framework of the EFOP-3.6.2-162017-00012 „Developing a functional, healthy and safe food product chain model from field to table in a thematic research network". The project is funded by the Hungarian State and the European Union, co-financed by the European Social Fund, and is part of the Széchenyi 2020 program.

\section{References}

[1] Bernáth J. (2013): Vadon termő és termesztett gyógynövények. Mezőgazda Kiadó

[2] Bolund, P. \& Hunhammar, S. (1999) Ecosystem services in urban areas. Ecological Economics , 29 , $293-301$.

[3] Braun-Blanquet, J. (1964) Pflanzensoziologie, Grundzüge der Vegetationskunde. 3rd Edition, Springer-Verlag, Berlin, 631 pp. http://dx.doi.org/10.1007/978-3-7091-8110-2

[4] Fuller, R.A., Irvine, K.N., Devine-Wright, P., Warren, P.H. \& Gaston, K.J. (2007) Psychological benefits of greenspace increase with biodiversity. Biology Letters , 3 , 390-394.

[5] N. B. Grimm, S. H. Faeth, N. E. Golubiewski, C. L. Redman, J. Wu, X. Bai, J. M. Briggs (2008): Global change and the ecology of cities. Science Vol. 319. Issue 586408 February 2008.

[6] Hoyk E. (2018): Adaptation possibilities to climate change with green infrastructure in urban environment. Abstract Book - 17th Alps-Adria Scientific Workshop 154-155.

[7] Stehlik, I., Caspersen, J.P., Wirth, L. \& Holderegger, R. (2007) Floral free fall in the Swiss lowlands: environmental determinants of local plant extinction in a peri-urban landscape. Journal of Ecology, 95, 734-744.

[8] Simon T. (2000): A magyarországi edényes flóra határozója. Tankönyvkiadó, Budapest. 